\title{
Economical Recovery of By-products
} in the Mining Industry

\author{
M. R. Ally \\ J. B. Berry \\ L. R. Dole \\ J. J. Ferrada \\ J. W. Van Dyke
}




\section{DOCUMENT AVAILABILITY}

Reports produced after January 1, 1996, are generally available free via the U.S. Department of Energy (DOE) Information Bridge.

Web site http://www.osti.gov/bridge

Reports produced before January 1,1996, may be purchased by members of the public from the following source.

National Technical Information Service
5285 Port Royal Road
Springfield, VA 22161
Telephone 703-605-6000 (1-800-553-6847)
TDD 703-487-4639
Fax 703-605-6900
E-mail info@ntis.fedworld.gov
Web site http://www.ntis.gov/support/ordernowabout.htm

Reports are available to DOE employees, DOE contractors, Energy Technology Data Exchange (ETDE) representatives, and International Nuclear Information System (INIS) representatives from the following source.

Office of Scientific and Technical Information

P.O. Box 62

Oak Ridge, TN 37831

Telephone 865-576-8401

Fax 865-576-5728

E-mail reports@adonis.osti.gov

Web site http://www.osti.gov/contact.html

This report was prepared as an account of work sponsored by an agency of the United States Government. Neither the United States Government nor any agency thereof, nor any of their employees, makes any warranty, express or implied, or assumes any legal liability or responsibility for the accuracy, completeness, or usefulness of any information, apparatus, product, or process disclosed, or represents that its use would not infringe privately owned rights. Reference herein to any specific commercial product, process, or service by trade name, trademark, manufacturer, or otherwise, does not necessarily constitute or imply its endorsement, recommendation, or favoring by the United States Government or any agency thereof. The views and opinions of authors expressed herein do not necessarily state or reflect those of the United States Government or any agency thereof. 


\section{Engineering Science and Technology Division Nuclear Science and Technology Division \\ Environmental Sciences Division}

ECONOMICAL RECOVERY OF BY-PRODUCTS IN THE MINING INDUSTRY

Date published—November 2001

Prepared by

OAK RIDGE NATIONAL LABORATORY

Oak Ridge, Tennessee 37831-6285

managed by

UT-BATTELLE, LLC for the

U.S. DEPARTMENT OF ENERGY under contract DE-AC05-00OR22725 


\section{CONTENTS}

LIST OF FIGURES $\ldots \ldots \ldots \ldots \ldots \ldots \ldots \ldots \ldots \ldots \ldots \ldots \ldots \ldots \ldots \ldots$

LIST OF TABLES $\ldots \ldots \ldots \ldots \ldots \ldots \ldots \ldots \ldots \ldots \ldots \ldots \ldots \ldots \ldots \ldots \ldots$

ACRONYMS AND ABBREVIATIONS $\ldots \ldots \ldots \ldots \ldots \ldots \ldots \ldots \ldots \ldots \ldots \ldots \ldots \ldots \ldots \ldots$

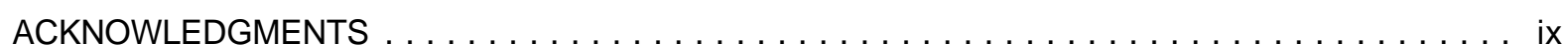

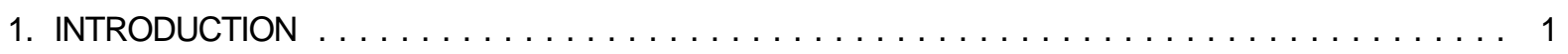

1.1 BY-PRODUCT RECOVERY OPPORTUNITIES $\ldots \ldots \ldots \ldots \ldots \ldots \ldots \ldots \ldots \ldots \ldots$

1.2 PROCESS RESIDUE VERSUS WASTE $\ldots \ldots \ldots \ldots \ldots \ldots \ldots \ldots \ldots \ldots \ldots \ldots$

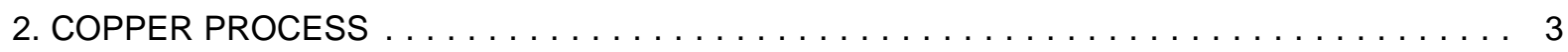

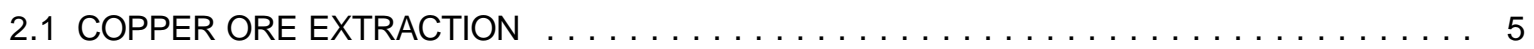

2.2 HYDROMETALLURGICAL PROCESSING $\ldots \ldots \ldots \ldots \ldots \ldots \ldots \ldots \ldots \ldots$

2.3 PYROMETALLURGICAL PROCESSING $\ldots \ldots \ldots \ldots \ldots \ldots \ldots \ldots \ldots \ldots$

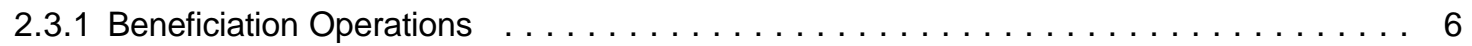

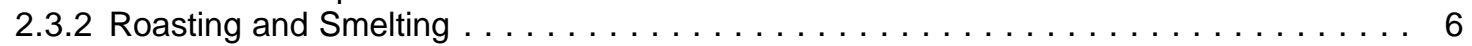

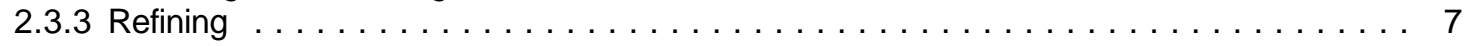

2.3.4 Gas Cleaning and Acid Production $\ldots \ldots \ldots \ldots \ldots \ldots \ldots \ldots \ldots \ldots \ldots$

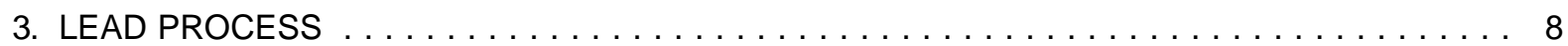

3.1 BENEFICIATING AND SMELTING LEAD ORE $\ldots \ldots \ldots \ldots \ldots \ldots \ldots \ldots \ldots$

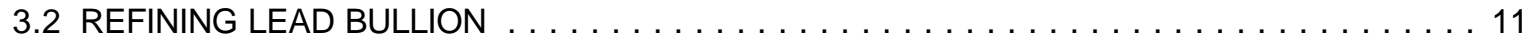

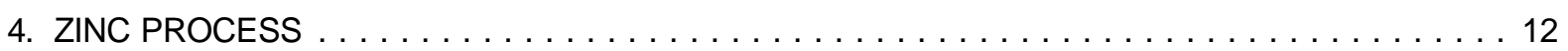

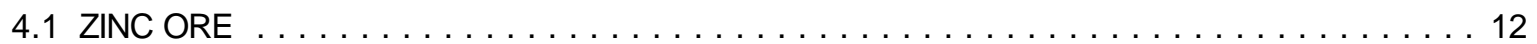

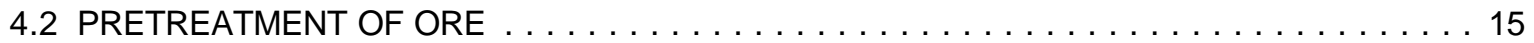

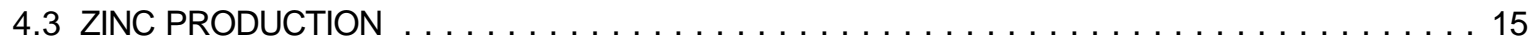

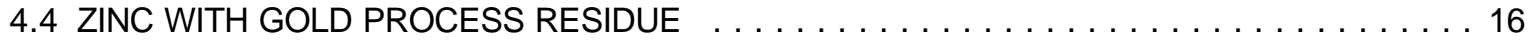

5. DATA NECESSARY TO EVALUATE BY-PRODUCT RECOVERY ECONOMICS $\ldots \ldots \ldots \ldots 17$

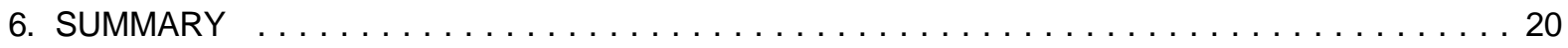

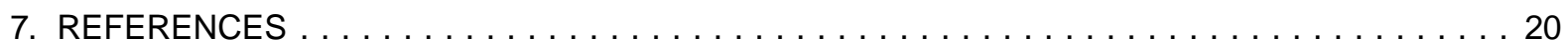

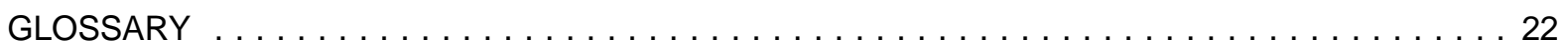




\section{LIST OF FIGURES}

1. Copper mining operations and by-product recovery opportunities $\ldots \ldots \ldots$

2. Details of copper mining operations and target process residue . . . . . . . . . . . . . 4

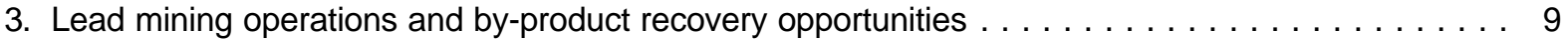

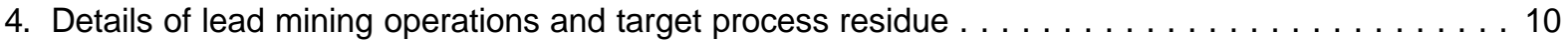

5. Zinc mining operations and by-product recovery opportunities $\ldots \ldots \ldots$

6. Details of zinc mining operations and target process residue . . . . . . . . . . . . . . 14

\section{LIST OF TABLES}

1. Distribution of elements in anode slime $\ldots \ldots \ldots \ldots \ldots$

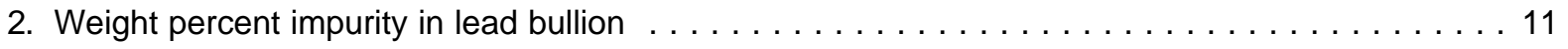

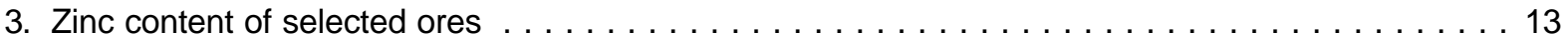

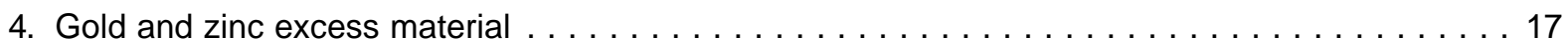

5. Economic variables for separation of impurities from process residue . . . . . . . . . . . . . 18 


\section{ACRONYMS AND ABBREVIATIONS}

$\begin{array}{ll}{ }^{\circ} \mathrm{C} & \text { degrees Celsius } \\ \text { DOE } & \text { U.S. Department of Energy } \\ \text { g } & \text { gram } \\ \text { NMA } & \text { National Mining Association } \\ \text { NRC } & \text { National Research Council } \\ \text { ORNL } & \text { Oak Ridge National Laboratory } \\ \text { RCRA } & \text { Resource Conservation and Recovery Act } \\ \text { SXEW } & \text { solvent extraction and electrowinning } \\ \text { vol \% } & \text { volume percent } \\ \text { wt \% } & \text { weight percent }\end{array}$

\section{Element abbreviations}

$\begin{array}{ll}\mathrm{Ag} & \text { silver } \\ \mathrm{Al} & \text { aluminum } \\ \mathrm{As} & \text { arsenic } \\ \mathrm{Au} & \text { gold } \\ \mathrm{Bi} & \text { bismuth } \\ \mathrm{Cd} & \text { cadmium } \\ \mathrm{Co} & \text { cobalt } \\ \mathrm{Cr} & \text { chromium } \\ \mathrm{Cu} & \text { copper } \\ \mathrm{Fe} & \text { iron } \\ \mathrm{Ga} & \text { gallium } \\ \mathrm{Ge} & \text { germanium } \\ \mathrm{Hg} & \text { mercury } \\ \mathrm{In} & \text { indium } \\ \mathrm{Mg} & \text { magnesium } \\ \mathrm{Mn} & \text { manganese } \\ \mathrm{Mo} & \text { molybdenum } \\ \mathrm{Nb} & \text { niobium } \\ \mathrm{Ni} & \text { nickel } \\ \mathrm{Pb} & \text { lead } \\ \mathrm{S} & \text { sulfur } \\ \mathrm{Sb} & \text { antimony } \\ \mathrm{Se} & \text { selenium } \\ \mathrm{Si} & \text { silicon } \\ \mathrm{Sn} & \text { tin } \\ \mathrm{Te} & \text { tellurium } \\ \mathrm{Tl} & \text { thallium } \\ \mathrm{V} & \text { vanadium } \\ \mathrm{W} & \text { tungsten (preferred term in the United States) or wolfram (preferred primarily in Europe) } \\ \mathrm{Zn} & \text { zinc } \\ \end{array}$




\section{ACKNOWLEDGMENTS}

The authors are indebted to National Mining Association members who reviewed and commented on this report. These comments improved the document and provided valuable insight into mining practices. The authors also recognize Charles Hagan of ORNL for his diligence in editing and clarifying technical descriptions while ensuring that mining terms are clearly defined. We greatly appreciate his contribution. 


\section{INTRODUCTION}

The U.S. Department of Energy (DOE) Office of Industrial Technologies, Mining Industry of the Future Program, works with the mining industry to further the industry's advances toward environmental and economic goals. Two of these goals are (1) responsible emission and by-product management and (2) low-cost and efficient production (DOE 1998). DOE formed an alliance with the National Mining Association (NMA) to strengthen the basis for research projects conducted to benefit the mining industry. NMA and industry representatives actively participate in this alliance by evaluating project proposals and by recommending research project selection to DOE. Similarly, the National Research Council (NRC) has recently and independently recommended research and technology development opportunities in the mining industry (NRC 2001). The Oak Ridge National Laboratory (ORNL) and Colorado School of Mines engineers conducted one such project for DOE regarding by-product recovery from mining process residue. The results of this project include this report on mining industry process residue and waste with opportunity for by-product recovery.

The U.S. mineral processing industry produces over 30,000,000 metric tons per year of process residue and waste that may contain hazardous species as well as valuable by-products. This study evaluates the copper, lead, and zinc commodity sectors which generate between $23,300,000$ and $24,000,000$ metric tons per year. The distribution of residual elements in process residues and wastes varies over wide ranges because of variations in the original ore content as it is extracted from the earth's crust. In the earth's crust, the elements of interest to mining fall into two general geochemical classifications, lithophiles and chalcophiles (Cox 1997). Groups of elements are almost always present together in a given geochemical classification, but the relative amounts of each element are unique to a particular ore body.

This paper generally describes copper, lead, and zinc mining operations and their associated process wastes and residues. This description can serve as a basis for identifying those process residues and waste that contain both impurities and products which currently cannot be economically recovered. This information could be used to develop a market-based approach to by-product recovery by evaluating potential revenue generated from the sale of by-products along with innovative recovery techniques.

Toward this end, the report is also intended to facilitate discussions between researchers and mining company representatives to clarify by-product recovery opportunities. The document is intended to provide easy-to-understand descriptions of mining processes. Process descriptions can be used by mining industry representative, who are experts in their field, to communicate with other mining representatives to discuss common problems without disclosing proprietary information and with researchers who have technical expertise but who are not familiar with the mining industry. This collaboration may lead to joint government-industry research projects on by-product recovery processing methods that promise to be economic for the mining industry.

By aiding communication between government researchers and industry representatives, the authors seek to identify research and development projects that would result in by-product recovery to benefit the mining industry. Evaluation of opportunities to recover by-products could be focused by using criteria such as favorable economics and reduced environmental impact. Key factors that influence the economics of by-product recovery are costs of managing the process residue as a waste (e.g., storage and/or disposal), the cost of the process residue before additional processing, the value of residuals and products after processing, and the processing cost.

\footnotetext{
* See, for example, the range of elements in anode slime given in Table 1.

Lithophilic elements are found in oxide minerals and, to a lesser extent, as halides. Examples include Fe, $\mathrm{Co}, \mathrm{Cu}, \mathrm{Zn}, \mathrm{Mg}, \mathrm{V}, \mathrm{Cr}, \mathrm{Nb}, \mathrm{Al}$, and Si. Chalcophilic elements are found in combinations with S, Se, and As. Examples include $\mathrm{Fe}, \mathrm{Cu}, \mathrm{Pb}, \mathrm{Cd}, \mathrm{Sn}, \mathrm{Hg}, \mathrm{Sb}, \mathrm{Mo}, \mathrm{W}$, Te, and $\mathrm{Ag}$. Some key elements are both lithophiles and chalcophiles: Fe, Co, Ni, Cu, Zn, Ga, Ge, Sb, and Pb.
} 


\subsection{BY-PRODUCT RECOVERY OPPORTUNITIES}

ORNL's preliminary evaluation of mineral mining operations identified opportunities for by-product recovery in the following categories:

- dust and fine particles,

- tailings,

- slag waste,

- gas cleaning sludge,

- liquor residues,

- dewatering and conserving water,

- suppression of undesirable elements in solution,

- removal of metals and nitrate from large volumes of wastewater, and solvent extraction and electrowinning (SX/EW).

The subsequent analyses of the three processes considered in this report identified the following process residues and waste as having by-product recovery potential:

- copper-dust and fine particles, tailings, slag waste, and gas cleaning sludge;

- lead-dust and fine particles, tailings, slag; and

- zinc-dust and fine particles, liquor residues, suppression of undesirable elements in solution, slag.

Project engineers concluded that gold mining is highly developed, presenting little opportunity for additional recovery of gold; however, other commodity metals (e.g., zinc) could be recovered from gold processing residue. While the other mineral mining operations are also efficient, opportunities for by-product recovery may exist. For example, one mine recently started a by-product recovery project by processing tailings with concentrations of $0.1-0.7 \% \mathrm{Cu}$. (The raw ore has copper concentrations of about $0.3-0.5$ wt \%.) In a recent survey of mining company representatives, opportunities for research and development on downstream technologies were highlighted, reflecting "the fact that productivity gains tend to increase as value is added to a product while it moves downstream" (Peterson, LaTourrette, and Bartis 2001).

\subsection{PROCESS RESIDUE VERSUS WASTE}

The distinction between process residue and waste is important. Different regulatory requirements (i.e., RCRA) apply to wastes, which are actually discarded (e.g., tailings and slag), than to process residues, which are not discarded but are reprocessed. Case law clarified this distinction, (e.g., AMC v. EPA, 824 F.2d 1177, D.C. Cir. 1987 and Association of Battery Recyclers v. EPA (208 F.3d 1047, D.C. Cir. 2000). For the purpose of this report, the authors choose to use the term "process residue" rather than "wastes." This choice was made to emphasize the purpose of the report - to identify opportunities to recover by-products.

Whether material is a waste or process residue depends on the technology applied to that material. By definition, reprocessing is planned for process residues using existing technology. More aggressive reprocessing technology, than is currently used, would be required to recover additional by-products from existing process residue. Reprocessing of wastes could result in the recovery of valuable elements from the mixture of elements that is inherent in ore. If a new reprocessing technology were researched, developed and deployed waste could be reclassified as process residue. Therefore, the availability of technology to recover by-products affects whether material is classified as waste or process reside. Since the purpose of this report is to identify opportunities for additional by-product recovery, the authors identify material with potential for by-product recovery as "process residue." 


\section{COPPER PROCESS}

ORNL engineers evaluated copper mining operations, prepared both simplified and detailed flow diagrams of those operations (USGS 2001), and identified process residues with by-product recovery potential (see Figs. 1 and 2). The United States currently holds $16 \%$ of the world's refined copper reserves in 30 active mines. Fifteen copper mines located in Arizona, New Mexico, Utah, Michigan, and Montana produced $99 \%$ of domestic production in 2000 (NMA 2001). The U.S. copper commodity sector generates 10,500,000-11,000,000 metric tons per year of "waste streams likely subject to U.S. Environmental Protection Agency Land Disposal Restrictions" (EPA 1998). These process residues include

- dust and fine particles,

- tailings,

- slag waste, and

- gas cleaning sludge.

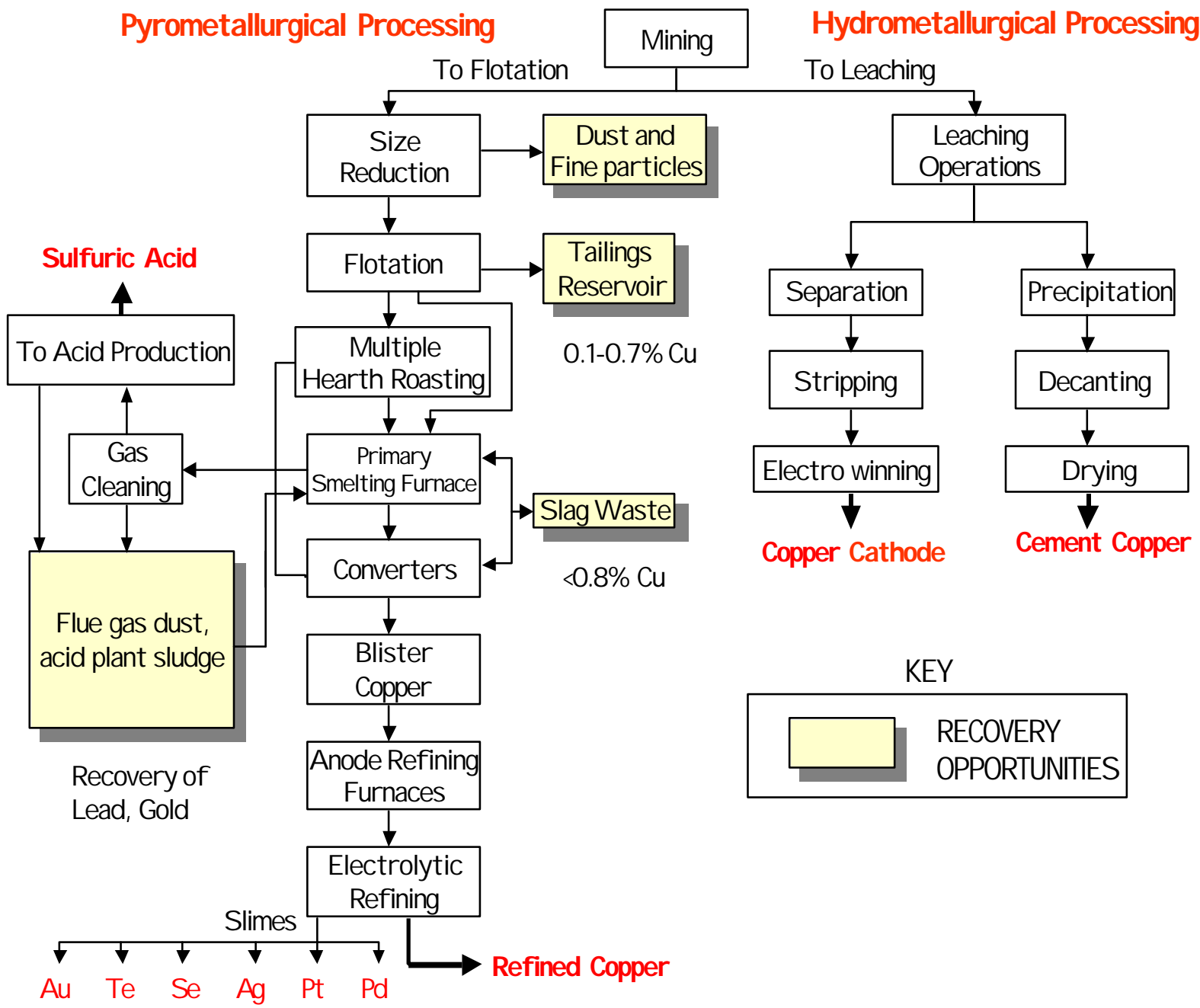

Fig. 1. Copper mining operations and by-product recovery opportunities. 


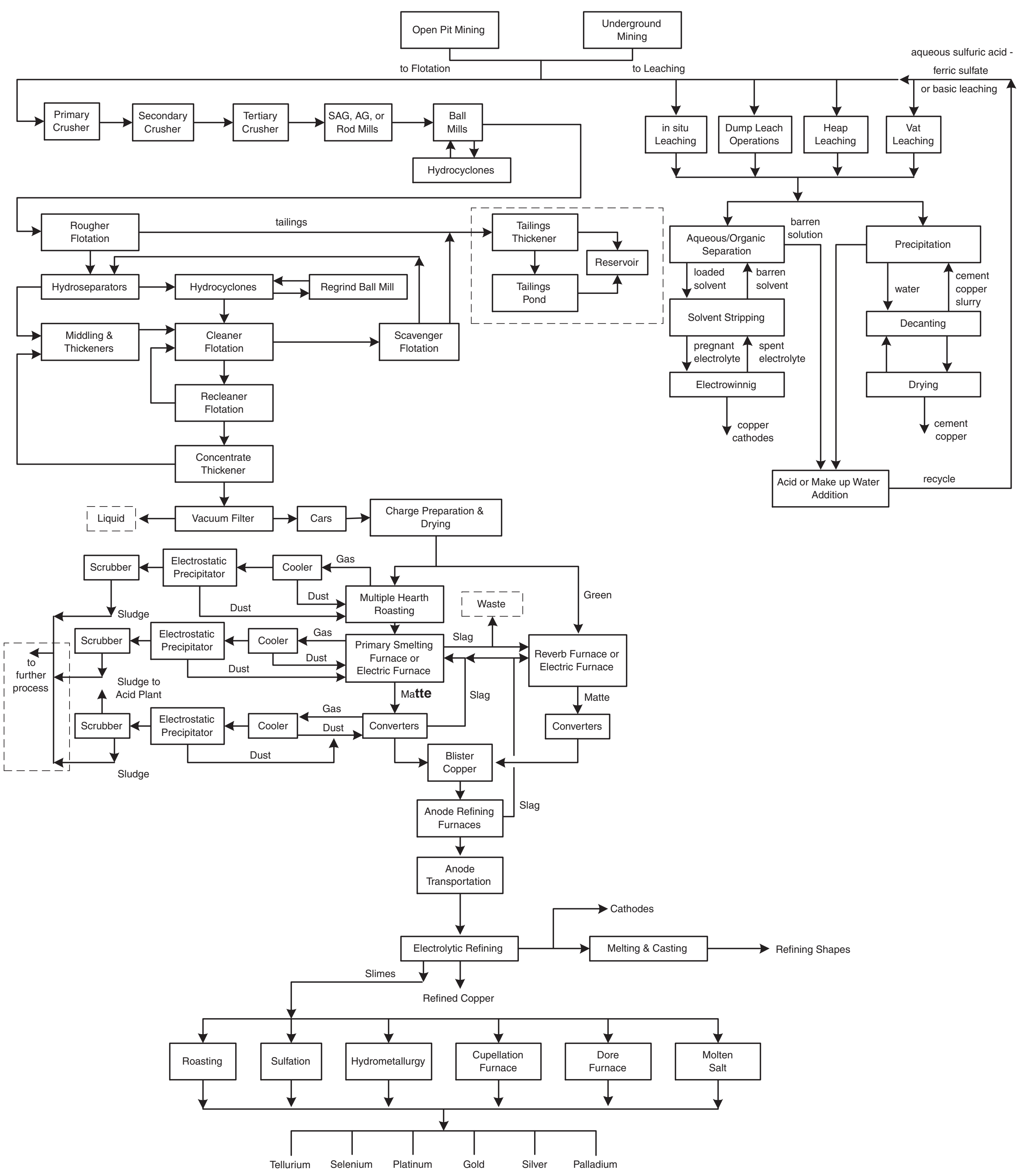

Fig. 2. Details of copper mining operations. 


\subsection{COPPER ORE EXTRACTION}

There are two basic methods of extracting copper ore: surface and underground mining. Copper is extracted from the ore in two ways, through hydrometallurgical and pyrometallurgical process. Surface open-pit mining is the predominant method used today by the U.S. copper mining industry, representing $83 \%$ of domestic mining capacity. Ore mined from open pits contains about $0.3-0.5$ wt $\% \mathrm{Cu}$, typically in the sulfide form. Copper concentrations of at least $1 \mathrm{wt} \%$, along with other valuable metals, are obtained from underground mines. Solution mining of copper oxide and sulfide ores has increased since 1975. In 1991, U.S. mines leached 15.7 million metric tons of copper ore to recover 441,000 metric tons of copper.

\subsection{HYDROMETALLURGICAL PROCESSING}

Copper is extracted from the ore by dissolution in a dilute aqueous solution of sulfuric acid. The ore is leached either by directly applying the aqueous solution or by applying water that reacts with the ore to form the solution (leachate). In some cases, ferric sulfate is also naturally generated during the leaching of sulfide ore where it becomes part of the leachate. This method is suitable for lowgrade copper ore bodies for which customary mining operations would be uneconomical, as well as for the leaching of remnant ores from abandoned mines. Leaching methods include dump, heap, and vat leaching techniques, as well as underground (or in situ) leaching methods. Underground leaching methods are currently not used in the U.S. However, some leaching of ore rubble (piles created by blasting) occurs underground. Some domestic copper mining companies are leaching old tailings to recover copper that could not be processed using techniques available at the time. Leaching operations are mainly applied to ores, low-grade sulfide ores and waste materials (Biswas and Davenport 1994).

Several techniques are used to extract copper-some ore is roasted or calcified before leaching, while other ore is subjected to microbial leaching. However, U.S. copper is not extracted by these methods. Zambia and Zaire leach roaster calcines to extract $\mathrm{Cu}$ and $\mathrm{Co}$ from Co-Cu-Fe-S concentrates. Bacteria that exist naturally within sulfide mine water, when combined with dilute sulfuric acid to form the leach solution, can facilitate the leaching process of sulfide ores or waste material.

Copper is recovered from leach solutions through precipitation or by solvent extraction. The reduction and precipitation of copper from dilute sulfuric acid leach solutions by iron is the oldest hydrometallurgical method. In practice, iron scrap, if possible sheet iron, or sponge iron with a large surface is used. The precipitation is carried out in vessels such as launders, cells, tanks, and special cone precipitators. The precipitate, cement copper, is an impure copper, from about $60 \mathrm{wt} \%$ to $>90$ wt \% Cu. Further treatment is usually by a pyrometallurgical process. Only one mining company operates a precipitation plant in the U.S. that processes meteoric water collected from waste rock dumps. Active leaching (spraying water) on the waste rock dumps was stopped in September 2000.

The copper solvent extraction consists of contacting pregnant aqueous leach solution with $\mathrm{Cu}$ specific organic liquid extractant. The $\mathrm{Cu}$-loaded organic extractant is then separated from the aqueous solution (raffinate). Raffinate is sent back to leaching. The Cu-loaded organic extractant is contacted with high- $\mathrm{H}_{2} \mathrm{SO}_{4}$ electrowinning electrolyte causing transfer of $\mathrm{Cu}$ into the high $-\mathrm{H}_{2} \mathrm{SO}_{4}$ electrolyte. The now-stripped organic extractant is returned to renewed contact with the pregnant leach solution. The enriched electrolyte is sent to electrowinning where metallic copper is removed by electroplating. The organic solvent is separated in a settler and stripped with concentrated sulfuric acid to produce a clean, high-grade solution of copper for electrowinning. These processes produce copper cathode and cement copper. Analysis of hydrometallurgical processing did not reveal opportunities for by-product recovery.

\subsection{PYROMETALLURGICAL PROCESSING}

About $80 \%$ of the primary copper in the world comes from low-grade or poor sulfide ores, which are usually treated by pyrometallurgical methods, generally in the following sequence: 
- beneficiation by froth flotation of ore to copper concentrate

- optional partial roasting to obtain oxidized material or calcified material

- two-stage pyrometallurgical extraction

- smelting concentrates to matte

- converting matte to blister copper

- refining the crude copper, usually in two steps:

- pyrometallurgically to fire-refined copper

- electrolytically to high-purity electrolytic copper

\subsubsection{Beneficiation Operations}

Excavated ores are reduced to a pulp by adding water and crushing in jaw, gyratory, and cone crushers, then sized with vibrating screens. This mixture of water and ore, pulp, is ground in rod and ball mills or, more recently, semi-autogenously (SAG) or autogenously (AG) milled before particles are separated according to size using classifiers and hydro cyclones.

Most sulfide copper ores must be beneficiated to increase the metal content. The essential operation is froth flotation, which is usually carried out in two successive steps: collective or bulk flotation for concentrating all the metal-containing minerals and, if necessary, selective flotation to separate various minerals. Flotation using frothers, collectors, activators, depressors, and reagents to control the $\mathrm{pH}$ (e.g., lime) and separates the feed pulp into metal sulfide groups. In simple cases, the flotation cells are combined into three groups: (1) rougher flotation for sorting into pre-concentrate and tailings, (2) cleaner flotation for post-treatment of the pre-concentrate, and (3) scavenger flotation for post-treatment of the tailings from the first step. The next step is solid-fluid separation using sedimentation in settlers and thickeners with subsequent vacuum filtering by drum and disk filters. The copper content of dried chalcopyrite concentrates (CuFeS $)_{2}$ ) averages $20-30$ wt \%.

Two copper-containing materials are produced during beneficiation operations. The first is dust and fine particles produced during the size reduction stages and the second is tailings generated by the flotation process. Some copper companies are recovering copper from tailings piles - for example, the Magma BHP-Billiton Pinto (formerly Magma Pinto Company) at its Pinto Valley operation. These tailings were deposited between 1911 and 1932. Pinto Valley hydraulically mines the tailings pile, leaches the tailings, and produces copper by using the SX/EW facility. After the tailings are leached and washed, the remaining slurry is pumped approximately five miles to an abandoned open-pit copper mine for final disposal. The pile's oldest tailings contain $0.72 \% \mathrm{Cu}$, while the most recently generated deposits contain $0.11 \% \mathrm{Cu}$. Magma strips the top layer of tailings to gain access to older material that can be economically recovered (Ullmann's 1993, Vol A7).

\subsubsection{Roasting and Smelting}

The product of flotation, copper mineral concentrate, contains $60-80 \%$ water. After filtration a relatively dry copper concentrate is processed in a smelter. Roasting may be used to prepare sulfide concentrates for subsequent pyrometallurgical or hydrometallurgical operation. The roasting decreases the sulfur content to an optimum level prior to smelting to form copper matte.

Smelting of un-roasted or partially roasted sulfide ore concentrate produces two immiscible molten phases: a heavier sulfide phase containing most of the copper, the matte, and an oxide phase, the slag. Matte is an intermediate phase in the copper pyrometallurgical processes because of the extractive metallurgy of copper. The pyrometallurgical production of copper from sulfide ore concentrates is a rough separation of the three main elements as crude copper, iron (II) silicate slag, and sulfur dioxide. Slag containing $<0.8 \mathrm{wt} \%$ copper is either discarded as waste or sold as product. Modern copper smelting processes produce high-grade mattes - the short residence time of the materials in the reaction chamber does not allow chemical equilibrium. Both factors contribute to a high concentration of copper in the slag, generally $>1 \mathrm{wt} \%$. Special methods are required to recover copper from slag.

Prior to the 1960s, the most important method for producing copper was roasting sulfide concentrates, smelting in calciners in reverberatory furnaces, and converting the matte in Pierce- 
Smith converters. Since that time, the modern flash smelting process with subsequent conversion has become predominant. There are several types of smelting processes that are presently used.

While still in the molten state, matte produced by smelting is concentrated, or converted, using forced air. Copper and iron sulfides, the main constituents of matte, are oxidized to a crude copper, ferrous silicate slag, and sulfur dioxide. Conventional conversion of matte is a batch process. The first step yields an impure copper (I) sulfide called "white metal" containing about 75-80 wt \% Cu. The second step, the converter, produces blister copper that averages 98-99 wt \% Cu.

Slag from the first step contains iron (II) silicates (40-50 wt \% Fe) with high magnetite content (15-30 wt \% $\mathrm{Fe}_{3} \mathrm{O}_{4}$ ). Reaction with air and formation of copper (I) oxide can increase the initial copper concentration from 3-8 wt \% to $15 \mathrm{wt} \%$ in the slag. Additional copper can be removed from the slag by returning it to the smelting unit or by froth flotation. The second step uses a high viscosity small-volume converter to form copper (I) oxide or silicate copper $(20-40 \mathrm{wt} \% \mathrm{Cu}$ ). When a sufficient quantity of slag $(<0.8 \mathrm{wt} \% \mathrm{Cu})$ has accumulated, it is returned to the first converting stage or purged.

\subsubsection{Refining}

Three stages are involved in conventional refining: (1) pyrometallurgical or fire refining, (2) electrolytic refining, and (3) re-melting of cathodes that are out of spec and casting of shapes. Fire refining is applied to crude copper from converters (about 97-99 wt \% Cu), black copper from blast furnaces (90-95 wt \% Cu), cement copper from hydrometallurgical operations (85-90 wt \% Cu), and anode scrap from electrolytic refining.

About $80 \%$ of the world copper production uses refining by electrolysis. This treatment yields copper with high electrical conductivity and separates valuable impurities, especially precious metals. Cathode copper is currently produced with purities ranging from 99.97 to $99.99 \%$. Insoluble substances are $<1 \%$ of the anode weight-these impurities collect on the bottom of the cells as anode slime. Slime contains precious metals (silver, gold, and platinum), selenides and tellurides of copper and silver, lead sulfate, stannic oxide hydrate, and complex compounds of arsenic, antimony, and bismuth. The distribution of the elements varies over wide ranges (see Table 1).

\begin{tabular}{lc}
$\begin{array}{c}\text { Table 1. Distribution of elements in } \\
\text { anode slime }\end{array}$ \\
\hline \multicolumn{1}{c}{ Element } & $\begin{array}{c}\text { Distribution } \\
\text { (wt \%) }\end{array}$ \\
\hline Copper & $20-50$ \\
Nickel & $0.5-2$ \\
Lead & $5-10$ \\
Arsenic & $0.5-5$ \\
Antimony & $0.5-5$ \\
Bismuth & $0.5-2$ \\
Tellurium & $1-4$ \\
Silver & $=25$ \\
Gold & $=4$ \\
\hline
\end{tabular}

Copper cathodes are re-melted and cast into final products because their electro-crystalline structure may not be suitable for working to semi-finished products. Although separation techniques differ greatly from plant to plant, anode slimes are generally treated as follows:

- leaching with dilute sulfuric acid to oxidize copper,

- recovery of selenium and tellurium by pyrometallurgical or hydrometallurgical methods,

- removal of unwanted elements and production of silver alloy, and

- separation of precious metals by electrolysis (silver and gold) and fractional precipitation (platinum metals). 


\subsubsection{Gas Cleaning and Acid Production}

Waste gases from the roasting operation are separated from flue dust at $1250^{\circ} \mathrm{C}$ in the off-take shaft and pass through a waste boiler that generates steam, and subsequently to an electrostatic precipitator to separate the bulk of the flue dust, which is recycled to the feed. The sulfur dioxide gas, which contains $>8 \% \mathrm{SO}_{2}$, also contains inorganic molecules of zinc, lead, copper, cadmium, mercury, bismuth and selenium. Common ionic species include sulfites $\left(\mathrm{SO}_{3}\right)$, sulfates $\left(\mathrm{SO}_{4}\right)$, and chlorides. Typically, there are also trace quantities of hydrocarbons and precious metals present in the gas stream. Impurities are removed from the gas stream-typically, gases are routed through bag-houses to remove coarse entrained particulate matter (i.e., bag-house dust). The flue dust consists chiefly of sulfates of copper, lead, and zinc and other sulfates, as well as some volatile compounds of arsenic, antimony, bismuth, and selenium. The cleaned off-gas is usually processed to form sulfuric acid.

Sulfur dixoide generated by the smelting process is retained and processed to make commercial grade sulfuric acid by-product. The gas cleaning section of the acid plant consists of venturi scrubbers, wash towers, and electrostatic precipitators. The vapor stream entering the acid plant is fed counter-flow through a spray of diluted sulfuric acid in the scrubbers. The scrubbers produce a large quantity of wet solids. The gas stream exiting the scrubbers is fed to the wash towers. Again, the vapor stream is fed counter-flow through a spray of sulfuric acid acting as a scrubber. The wash towers also produce a wet solid, which is fed via slurry pumps to a storage tank. The process recirculates most of the scrubber water; however, a small percentage of the stream must be purged (i.e., blown down) periodically to prevent buildup of solids and to minimize corrosion of the scrubber systems. The vapor stream leaving the wash towers enters a series of electrostatic precipitators. The sulfur dioxide $\left(\mathrm{SO}_{2}\right)$ that is released from the pyrometallurgical processing of sulfide ores is converted to sulfur trioxide $\left(\mathrm{SO}_{3}\right)$ over a vanadium pentoxide catalyst $\left(\mathrm{V}_{2} \mathrm{O}_{5}\right)$ at $430^{\circ} \mathrm{C}$. The $\mathrm{SO}_{3}$ is then contacted with water to form sulfuric acid $\left(\mathrm{H}_{2} \mathrm{SO}_{4}\right)$ via the following reaction:

$$
\mathrm{SO}_{3} \text { (gas) }+\mathrm{H}_{2} \mathrm{O} \quad \mathrm{H}_{2} \mathrm{SO}_{4} \text { (aqueous) } \Delta \mathrm{G}=-35 \text { to }-25 \mathrm{kcal} / \mathrm{mole} \text { at } 20^{\circ} \text { to } 110^{\circ} \mathrm{C}
$$

The $\mathrm{SO}_{3}$ contained in the gas is converted to $\mathrm{SO}_{4}$ using vanadium pentoxide $\left(\mathrm{V}_{2} \mathrm{O}_{5}\right)$ at $430^{\circ} \mathrm{C}(\mathrm{Patton}$ 2000). Liquid is separated from the wet solids that can be processed for recovery of by-products such as copper, gold, lead, and silver.

\section{LEAD PROCESS}

ORNL engineers evaluated lead-mining operations, prepared both simplified and detailed flow diagrams of those operations (Ullmann's 1993, Vol. A15), and identified process residues with byproduct recovery potential (see Figs. 3 and 4). The U.S. lead commodity sector generates 3,000,000$3,200,000$ metric tons per year of "waste streams likely subject to U.S. Environmental Protection Agency Land Disposal Restrictions." These process residues include

- dust and fine particles,

- tailings, and

- slag waste.

\subsection{BENEFICIATING AND SMELTING LEAD ORE}

Lead most often occurs in association with the sulfide mineral group. Lead ore deposits usually form with other minerals and the host rock. These crude ores cannot be directly smeltedbeneficiation must be used to concentrate the lead. Ore beneficiation normally includes crushing, dense-medium separation, grinding, froth flotation, and drying of concentrate (Biswas and Davenport 1994; DOE 1980). 


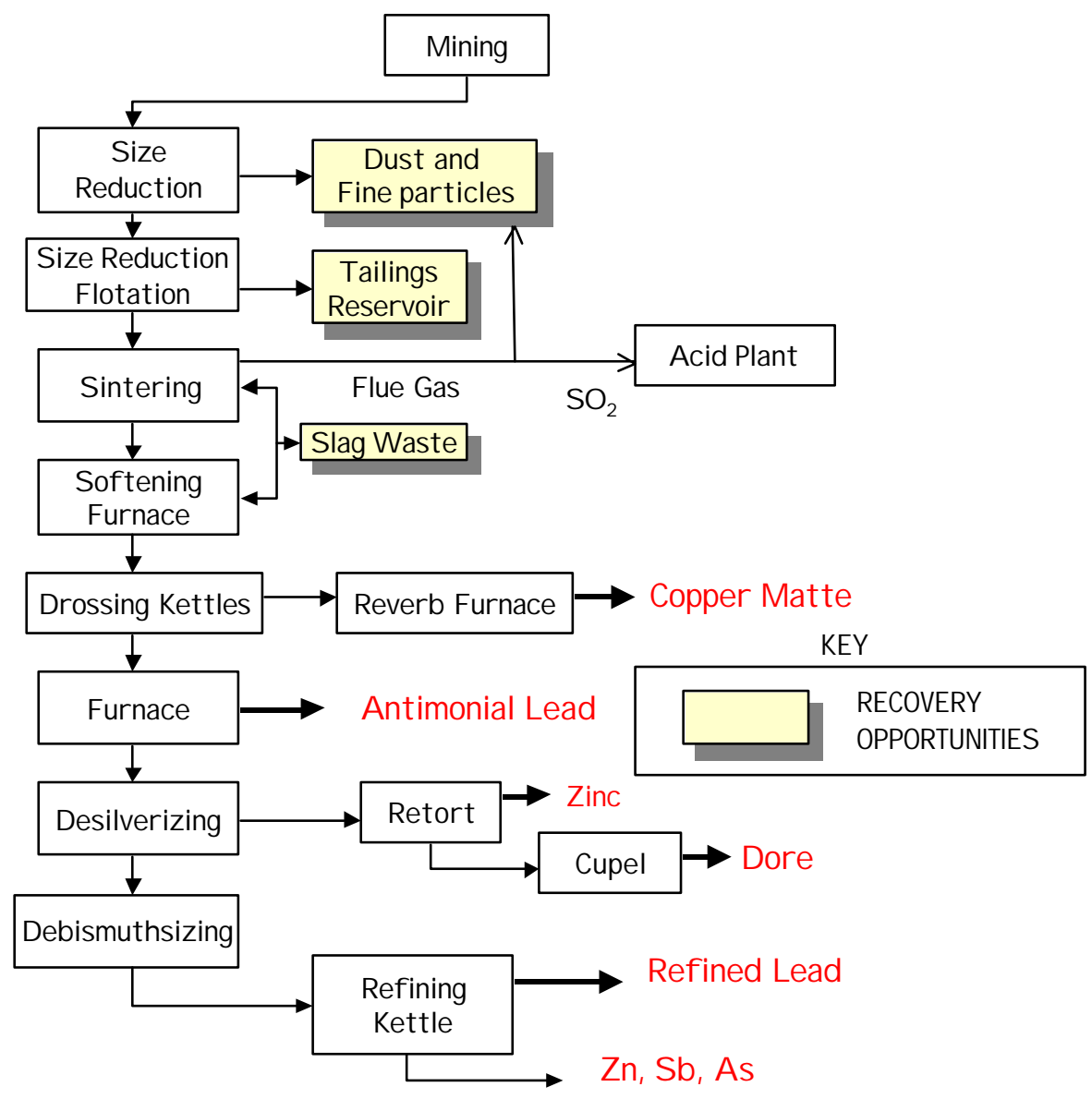

Fig. 3. Lead mining operations and by-product recovery opportunities.

Sinter oxidation using a blast furnace is the major method for producing lead from sulfide concentrate. In the past two decades, oxygen metallurgy processes have advanced to industrial applications that feature sulfide oxidation in a flash flame or by oxygen injection into a slag bath, followed by reduction of the lead oxide slag (Ullmann's 1993, Vol. A28).

One type of sintering roaster uses downdraft airflow to produce roasting gases with a concentration of 1-2 vol \% sulfur dioxide. Gases are re-circulated until acid-strength gas is produced. In this system, the molten lead flows downward through the sinter bed with the gas stream. Another type of roaster uses updraft airflow-sintering occurs in an ascending gas stream. A major problem for roaster operations is dust collection because high volumes of ventilation air are handled at considerable cost. Dust recovered from baghouses and wet scrubbers must be recycled to the process. The dust from sintering operations is usually collected in high-temperature electrostatic precipitators. Rich gas containing $\sim 6$ vol $\%$ sulfur dioxide can be delivered to a sulfuric acid plant. Flue dust from lead sintering plants contain $60-70 \%$ lead, about $10 \%$ sulfur, and varying amounts of zinc, cadmium, arsenic, antimony, and mercury. Flue dusts are recycled to the sinter bed.

The second part of the roast-reduction process is carried out in a blast furnace. The lead is mostly oxidized with coke. The sinter is charged to the blast furnace and metals are reduced to metallic lead, copper, antimony, arsenic, and noble metals. In some blast furnaces the zinc contained in the sinter remains in the slag. In others, zinc off-gas is condensed to liquid zinc metal. Noble metals are corrosion-resistant, metallic elements (e.g., the platinum group, gold, silver, and rhenium) 


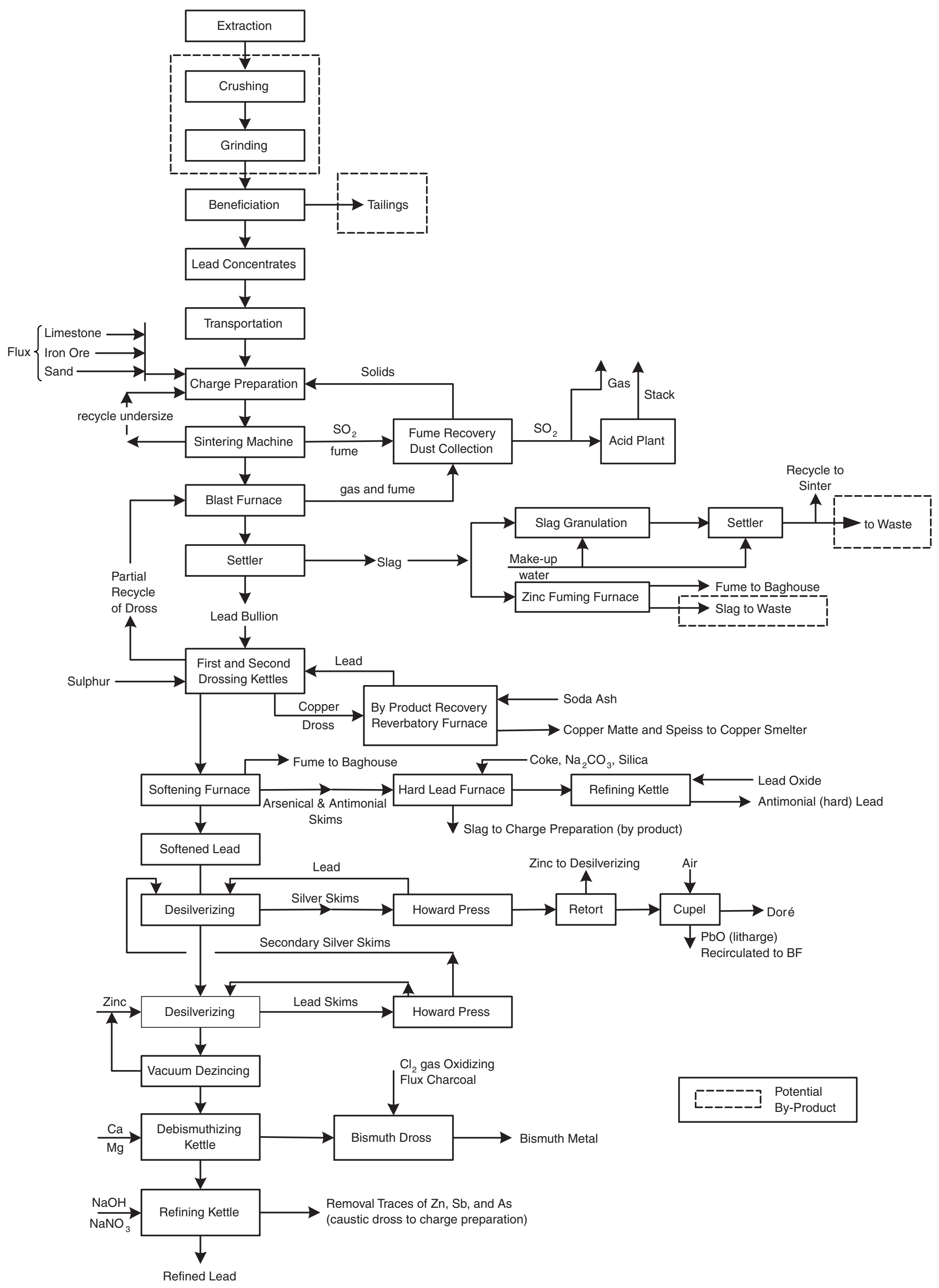

Fig. 4. Details of lead mining operations. 
that exchange electrons according to their position in the electrochemical series of metallic elements. Because of this preferential transfer of electrons, noble metals are largely dissolved in the lead product (bullion), with small amounts distributed to sulfide matte and slag. The copper contained in the sinter is captured in the bullion in the form of sulfide or metallic copper depending on the amount of sulfur present. Copper can report to the slag along with the zinc. Antimony and arsenic compounds are reduced to their respective metals, which dissolve in the lead bullion. The products of the lead blast furnace are

- lead bullion, that must be further refined.

- slag that may contain large quantities of zinc that may be further processed.

- flue and baghouse dusts that may contain cadmium. Leaching may be used to separate cadmium before dust is recycled to sintering.

- off-gas, which may contain about $4 \%$ carbon monoxide. After dust is removed, it is released to atmosphere.

- Matte, a sulfidic product of blast furnace smelting, forms only if the concentration of sulfur is high. Normally, subsequent reverberatory melting of lead bullion dross yields copper matte, lead metal, and slag.

- Speiss is formed when the concentration of arsenic, nickel, cobalt, and antimony is so high that these metals can no longer dissolve in the matte. Speiss is undesirable, because it dissolves large quantities of noble metals and is also expensive to refine.

Lead blast-furnace slag often contains sufficient zinc to make recovery profitable using various zinc fuming techniques. Zinc oxide in the slag is reduced to metallic zinc (vapor) by carbon, oxidized by secondary air, and carried out in the furnace gases for recovery of zinc oxide dust.

\subsection{REFINING LEAD BULLION}

The lead bullion contains numerous dissolved impurities. The lead content varies between 90 and $99 \%$ depending on the process and feed quality. Lead bullion can contain metallic impurities as shown in Table 2.

Table 2. Weight percent impurity in lead bullion

\begin{tabular}{cc}
\hline Impurity & $\begin{array}{c}\text { Quantity } \\
\text { (wt \%) }\end{array}$ \\
\hline $\mathrm{Cu}$ & $0.2-4.0$ \\
$\mathrm{Fe}$ & $0-0.5$ \\
$\mathrm{Zn}$ & $0-0.5$ \\
$\mathrm{Ni}$ & $0-0.1$ \\
$\mathrm{Co}$ & $0-0.1$ \\
$\mathrm{As}$ & $0-2.0$ \\
$\mathrm{Sb}$ & $0-6.0$ \\
$\mathrm{Ag}$ & $0-2.0$ \\
$\mathrm{Bi}$ & $0-6.0$ \\
$\mathrm{Sn}$ & $0-4.0$ \\
$\mathrm{~S}$ & typically $0.2-0.3$ \\
$\mathrm{O}$ & typically 0.1 \\
\hline
\end{tabular}

Pyrometallurgical and electrolytic refining are both used. The latter is generally reserved for high levels of impurity. Pyrometallurgical refining methods include chemical processes, precipitation processes, and distillation processes. In the chemical process, a reagent is added to the parent metal 
so it reacts with one or more impurity to form a compound that is insoluble in the parent metal. Selective oxidation, sulfurization, or chlorination can be used as the refining step. The precipitation process uses temperature decreases to make impurities insoluble in the metal. Alternatively, suitable reagents can form insoluble compounds that can be skimmed off (e.g., bismuth from lead-bismuth solutions after addition of calcium and magnesium). Distillation processes are employed when a large difference in vapor pressure exists between the parent metal and the impurity (e.g., in the separation of residual zinc from bullion after desilvering). Typical pyro-refining includes the following steps:

- removal of copper (decoppering) by precipitation followed by selective sulfidizing of copper;

- removal of arsenic, tin, and antimony by selective oxidation with injected air or oxidizing agent such as sodium nitrate;

- removal of noble metals is normally called desilverizing and involves intermetallic precipitation with zinc;

- removal of residual zinc after desilverizing by distillation;

- debismuthizing by precipitating bismuth with alkali metals; and

- removal of alkali metals and alkaline-earth metals after debismuthizing, which is called final refining and is performed by selective oxidation with air under a salt slag cover.

Refined lead contains arsenic, antimony, and tin at a level of $10-20 \mathrm{~g} / \mathrm{t}$, zinc corresponding to the final content in vacuum dezincing $(30 \mathrm{~g} / \mathrm{t})$, and calcium and magnesium corresponding to saturation limit. These impurities are reduced to below $1 \mathrm{~g} / \mathrm{t}$ by treatment with caustic soda.

The electrolytic refining of lead bullion from soluble anodes has been practiced for years in a number of large plants. Because of poor solubility, solutions have been restricted to the lead salts of fluosilicic acid, fluoroboric acid and amido-sulfuric acid. Metals with a higher electrochemical potential than lead (silver, gold, copper, bismuth, antimony, arsenic, and germanium) do not dissolve and accumulate in the anode slime that is processed to recover these valuable by-products.

\section{ZINC PROCESS}

ORNL engineers evaluated zinc-mining operations, as described below, and compiled flow diagrams of unit operations (Wiley 1984). We prepared both simplified and detailed flow diagrams of zinc mining operations and identified process residues with by-product recovery potential (see Figs. 5 and 6). The U.S consumes $18 \%$ of the total world's zinc production while it produces $11 \%$ of the world's zinc output (EPA 1994). ${ }^{5}$ The U.S. zinc commodity sector generates $9,800,000$ metric tons per year of "waste streams likely subject to U.S. Environmental Protection Agency Land Disposal Restrictions" (EPA 1998). These process residues include

- tailings,

- dust and fine particles,

- slag, and

- liquor residues.

\subsection{ZINC ORE}

Zinc is the $24^{\text {th }}$ element in order of abundance and occurs only in the chemically combined state. Like copper and lead, zinc is a strongly chalcophilic element, usually occurring as the sulfide. By far the most important zinc mineral today, and probably also the only primary ore, is zinc blende, sphalerite, ZnS, containing $67.09 \% \mathrm{Zn}$ and $32.91 \% \mathrm{~S}$ on a theoretical basis. The most important impurity in $\mathrm{ZnS}$ is $\mathrm{FeS}$ that can be present at concentrations varying from 0.3 to $>20 \%$. 


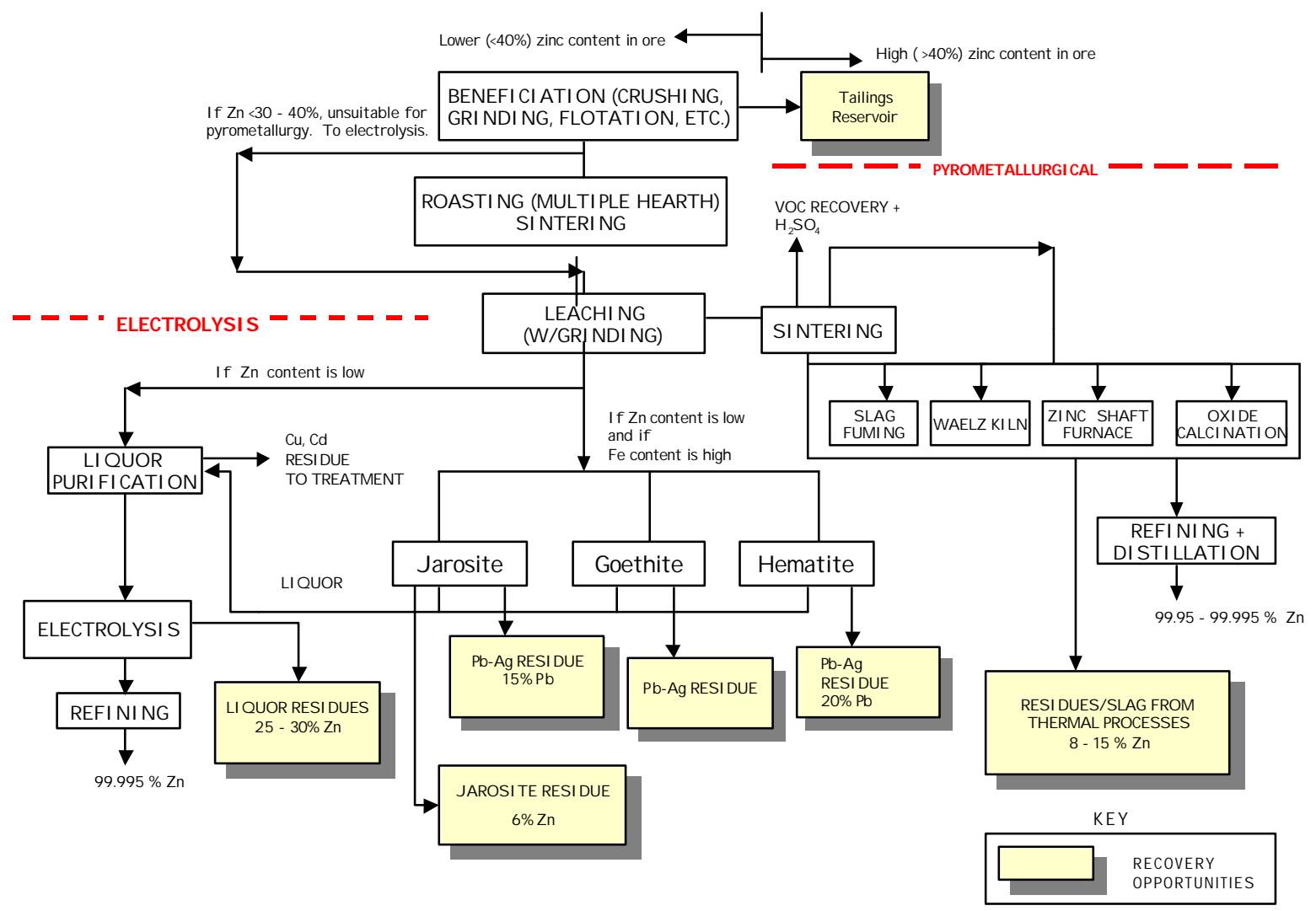

Fig. 5. Zinc mining operations and by-product recovery opportunities.

Sulfides of $\mathrm{Pb}, \mathrm{Cd}, \mathrm{Mn}$, and $\mathrm{Cu}$ are often present. Zinc blende also contains small amounts of As, Sn, $\mathrm{Bi}, \mathrm{Co}, \mathrm{Hg}$, In, TI, Ga, and $\mathrm{Ge}$ and nearly always contains $\mathrm{Ag}$ and often $\mathrm{Au}$. Other ores and their respective zinc contents are given in Table 3 .

Table 3. Zinc content of selected ores

\begin{tabular}{lc}
\hline \multicolumn{1}{c}{ Ore } & $\begin{array}{l}\text { Zinc content } \\
\text { (\% by mass) }\end{array}$ \\
\hline Smithsonite, $\left(\mathrm{ZnCO}_{3}\right)$ & $52.14 \mathrm{Zn}$ \\
Hemimorphite, $\mathrm{Zn}_{2} \mathrm{SiO}_{4} \cdot \mathrm{H}_{2} \mathrm{O}$ & $54.30 \mathrm{Zn}$ \\
Willemite, $\mathrm{Zn}_{2} \mathrm{SiO}_{4}$ & $58.68 \mathrm{Zn}$ \\
Franklinite, $(\mathrm{Zn}, \mathrm{Fe}, \mathrm{Mn}) \mathrm{O} \cdot\left(\mathrm{Fe}_{2}, \mathrm{Mn}_{2}\right) \mathrm{O}_{3}$ & $21 \% \mathrm{ZnO}$ \\
\hline
\end{tabular}




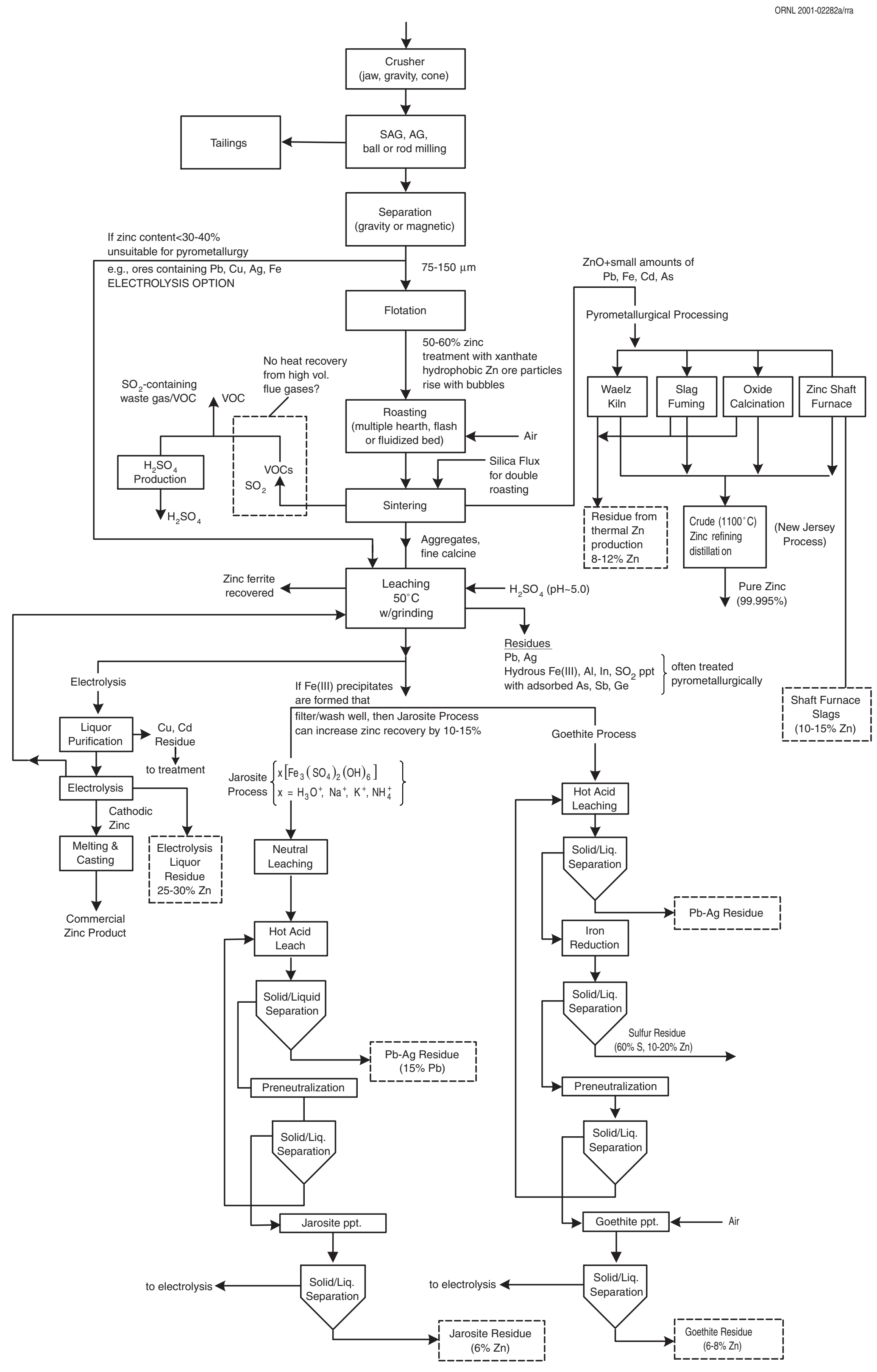

Fig. 6. Details of zinc mining operations. 
Other zinc minerals of lesser metallurgical importance include zinc bloom or hydrozincite, $\mathrm{ZnCO}_{3}$ • $n \mathrm{Zn}(\mathrm{OH})_{2}$; red zinc ore or zincite, $\mathrm{ZnO}$; and troostite or bainite, $(\mathrm{Zn}, \mathrm{Mn})_{2} \mathrm{SiO}_{4}$.

\subsection{PRETREATMENT OF ORE}

Pyrometallurgical and electrolytic zinc production requires an oxide raw material. Sulfide ores must be prepared for metal extraction by roasting, which removes the sulfur as $\mathrm{SO}_{2}$ and converts $\mathrm{ZnS}$ (zinc blende) to $\mathrm{ZnO}$, but does not remove gangue material. Most roasting is now done in multiple hearths or by flash roasting. An essential requirement of any roasting process is that it must be possible to recover and use the $\mathrm{SO}_{2}$ from the waste gas. The conversion of the sulfide form of the ore to the oxidic (calcined) form is done before leaching or reduction. The way an ore is prepared depends upon the zinc production process. A fine-grained calcine is necessary for leaching with dilute sulfuric acid. Such calcines are obtained in a fluidized bed. On the other hand, thermal processes require a porous feed material in lump form, as provided by sinter roasting.

\subsection{ZINC PRODUCTION}

After overburden, tailings are a second type of common mining waste. Most beneficiation processes generate tailings, which contain a mixture of impurities, trace metals, and residue of chemicals used in the beneficiation process. Tailings usually leave the mill as slurry consisting of 40 to $70 \%$ liquid mill effluent and 30 to $60 \%$ solids. Most mine tailings are impounded on-site.

There are five industrial processes for the production of zinc; one electrolytic and four pyrometallurgical. The four pyrometallurgical processes are slag fuming, Waelz kiln, zinc shaft furnace, and oxide calcination. If zinc content in the ore is greater than about $40 \%$, then the most likely route for zinc production is pyrometallurgy (see Fig. 5). If the zinc content of the ore is below $40 \%$, then electrolytic production of zinc may be more economical. Zinc produced electrolytically does not need to be refined. However, crude zinc produced by the pyrometallurgy contains $0.7-3 \% \mathrm{~Pb}$, up to $0.2 \% \mathrm{Fe}$, up to $0.3 \% \mathrm{Cd}$, and sometimes small amounts of As, depending upon the production method and the ore composition. Residues and slag from pyrometallurgical processes may contain 8$15 \%$ zinc, representing an opportunity for further recovery.

Once crude zinc is produced from one of the four pyrometallurgical processes, further purification is achieved by distillation. Distillation is feasible because of the relative differences in boiling points of zinc $\left(906^{\circ} \mathrm{C}\right.$ ) and cadmium $\left(762^{\circ} \mathrm{C}\right)$. Since $\mathrm{Cd}$ is usually an impurity and because the boiling point of $\mathrm{Cd}$ is comparatively close to $\mathrm{Zn}$, the distillation is carried out in two stages, the second of which is fractional distillation.

Zinc is produced electrolytically from dilute aqueous solutions of zinc sulfate in sulfuric acid although it can also be produced electrolytically from molten salts. The aqueous solution route is adopted in industry. Like the thermal processes of zinc production, the industrial electrolysis of zinc uses oxide starting-materials. The most important natural raw material, zinc blende, still needs to be roasted so it is converted to oxide. Using typical starting materials, the electrolytic process of zinc production consists of roasting, leaching, liquor purification, electrolysis and finally, melting and casting. The main problem in leaching and liquor purification is $\mathrm{Zn}$-Fe separation. High yield of zinc can be achieved only with Fe concentrations of $<3 \%$. As the Fe interferes with the electrolytic process even at low concentrations, it must be precipitated from the zinc sulfate solution.

Mineral formation has replaced the precipitation of iron hydroxide worldwide to enhance zinc production. In the jarosite process, an $\mathrm{Fe}(3+)$ compound of the type $\mathrm{X}\left[\mathrm{Fe}_{3}\left(\mathrm{SO}_{4}\right)_{2}(\mathrm{OH})_{6}\right]$ where $\mathrm{X}$ represents $\mathrm{H}_{3} \mathrm{O}^{+}, \mathrm{Na}^{+}, \mathrm{K}^{+}$, or $\mathrm{NH}_{4}^{+}$is precipitated by adding alkali metal or ammonium ions. These compounds correspond to the mineral jarosite. Precipitation of jarosite begins at $\mathrm{pH}<1$ and is complete at $\mathrm{pH} 1.5$. The jarosite process can achieve zinc yields of $96-98 \%$. Iron can also be removed from electrolytic solutions by the goethite process. Goethite is $\mathrm{FeO}(\mathrm{OH})$ formed at $\mathrm{pH}$ 2-3.5 and temperatures from 70 to $90^{\circ} \mathrm{C}$. The advantage of the goethite process is that the amount of residue that must be disposed of is considerably less than in the jarosite process, whereas the zinc yield is comparable to the jarosite process. The hematite process was developed to enable Fe- 
containing residues from zinc production to be disposed of at moderate cost and without ecological problems. It differs from the other processes in that the residues are subjected to reductive leaching in which the reducing agent is an excess of zinc concentrate.

Jarosite can theoretically contain $37 \%$ iron and $13 \%$ sulfur as sulfate. However, these values are not achieved in practice so that additional leaching processes are used to obtain zinc content of $4-6 \%$ in the residue. The goethite process improves upon the jarosite process because the solution from the first hot leach is treated with zinc concentrate. Excess zinc concentrate and elemental sulfur are recycled to the roasting process. These process improvements give the goethite the advantage of producing fewer residues. The hematite process enables iron-containing residue from zinc production to be disposed of at a moderate cost and without environmental problems or produced in the form of a useful by-product. However, the cost and complexity of the hematite processing technology restricts more widespread use of the process (Ullmann's 1993). As recognized by the NRC, mineral formation processes could potentially be improved by developing methods to suppress the solubility of undesirable elements in leach solutions.

An engineering evaluation of zinc processing operations identified potential opportunities for by product recovery. For example, dust and fine particles and slag is produced by thermal zinc operations contains $8-12 \%$ zinc. Liquor produced by zinc electrolysis contains $25-30 \%$ zinc.

\subsection{ZINC WITH GOLD PROCESS RESIDUE}

In the United States, about $60 \%$ of the gold production originates from ores and the remainder primarily from the refining of base metals (e.g., copper, zinc, lead, and mercury). Ongoing processes routinely recover gold from the processing of base metals. Therefore, this paper discusses recovery of zinc from gold processing. In gold processing, gold is recovered in several different ways. Electrolytic recovery of gold was popular but is now replaced by the Miller process in which chlorine is bubbled through molten metal, converting the base metals to volatile chlorides that are recovered downstream as vapors. More than two-thirds of all gold produced to date has been through the Miler process, which yields $99.5-99.6 \%$ gold. The Miller process is based on the fact that gold chlorides are unstable above $400^{\circ} \mathrm{C}$, and thus do not form at a reaction temperature of about $1100^{\circ} \mathrm{C}$, whereas the chlorides of base metals form stable volatile chlorides, which are collected downstream. The degree to which zinc is separated from other volatile chlorides and recovered, or the recovery of base metals altogether, is unclear and presents an opportunity to explore improvement of zinc recovery and waste mitigation.

Cyanide is also used to recover gold. In this process, the powdered mineral slurry which typically contains $10 \mathrm{ppm}$ gold in solid matter is treated with an aerated $0.03 \%$ cyanide solution. The "dead" powdered mineral is filtered off in rotary vacuum filters. Filter cake contains $<1 \mathrm{ppm}$ gold. The filtrate, which contains most of the gold from the mineral is treated with zinc chips to precipitate the gold:

$$
2 \mathrm{Na}\left[\mathrm{Au}(\mathrm{CN})_{2}\right]+\mathrm{Zn} ? \mathrm{Na}_{2}\left[\mathrm{Zn}(\mathrm{CN})_{4}\right]+2 \mathrm{Au}
$$

The raw gold is treated with sulfuric acid to remove excess zinc, dried, and then roasted in air at $800^{\circ} \mathrm{C}$ to oxidize lead, zinc, and iron. The solid mixture of lead, zinc, and iron might offer another opportunity for zinc recovery or as feedstock in another metallurgical process.

Carbon adsorption followed by electrowinning is the most common method of gold recovery domestically. Zinc precipitation is used to recover gold from ore, which contains large amounts of silver using the following processing steps: carbon adsorption; elution of carbon, forming a concentrated gold solution, filtration, and mixing with metallic zinc dust, causing a chemical reaction, which generates a gold precipitate. The solution is then forced through a filter that separates the gold. The high concentration of zinc in the gold precipitate presents an opportunity for zinc recovery especially since these operations produce large volumes of material. Gold mining generates 200$1,400,000$ metric tons per year of processing waste that are likely to contain hazardous species (EPA, 1998). However, the total waste produced is more than 540 million metric tons (see Table 4). 
Table 4. Gold and zinc excess material

\begin{tabular}{lcccc}
\hline Commodity & $\begin{array}{c}\text { Number of } \\
\text { mines }\end{array}$ & $\begin{array}{c}\text { Commodity } \\
\text { produced } \\
(\mathbf{1 , 0 0 0} \text { metric tons })\end{array}$ & $\begin{array}{c}\text { Tailings generated } \\
(\mathbf{1}, \mathbf{0 0 0} \text { metric tons })\end{array}$ & $\begin{array}{c}\text { Other waste } \\
\text { handled } \\
(\mathbf{1 , 0 0 0} \text { metric tons })\end{array}$ \\
\hline Gold & +212 & 0.329 & 247,533 & 293,128 \\
Zinc & 25 & 524 & 4,227 & --- \\
\hline
\end{tabular}

Similarly, it seems plausible that there is opportunity for zinc and aluminum recovery when gold is recovered from solution (lixiviant or eluate) by cementation with zinc or aluminum, although it is difficult to quantify this opportunity based on published data.

\section{DATA NECESSARY TO EVALUATE BY-PRODUCT RECOVERY ECONOMICS}

The mining by-product recovery project was directed to clarify opportunities to recover byproducts from mining process residue. Once a process residue is identified as having by-product recovery potential, researchers can technically evaluate methods to separate impurities from valuable elements (e.g., separate mercury from copper-bearing process residue). Further, evaluation of these opportunities would be focused by using criteria such as favorable economics and reduced environmental impact. However, developing data that can accurately describe the potential market and profitability of new technologies is a challenge. Data on the value of process residue before separating impurities, after separation, and the cost of separation are all necessary in order to evaluate a technology's market potential (Table 5). Additional data are required on the amount of process residue that is available for processing. If this information is known, then informed decisions about research, development, and demonstration are possible. Without these data, the economic potential for new technologies will be less certain and investments in the technology from government and/or private capital markets would be less likely.

For a number of reasons, data necessary to implement the heuristic model may be difficult to gather or develop. For instance, the cost of a new technology partly depends on developing the technology, manufacturing it, and implementing it. The realistic cost of the technology can only be known through experience. However, the values against which the viability of a new technology must be compared are "data" that describe the experiences of existing firms. Unfortunately, some of these values are proprietary and are only known with some accuracy by the companies that control the recovery of by-products and/or ultimate disposal of waste.

For instance, consider the cost to recover by-products from acid plant sludge generated as part of copper smelting operations and the value of those by-products. This process residue (acid plant sludge) has some initial value before impurities (mercury) are separated (Table 5, Row A). This value may be negative because the residue may be designated as "waste" if it cannot be reprocessed to recover some of the valuable components. The value (or cost) could be determined by the cost of transport and disposal of the sludge.

The primary process residue (acid plant sludge) may have a market value that is a function of the concentration of impurities (mercury) (Table 5, Row B). For example, process residue may be sold to a smelter to recover commodity metals (lead, silver, gold). If the residue includes impurities, such as mercury, the price the smelter pays the copper smelter could be more or less depending on the amount of impurity. Secondary process residue (mercury) may also have a market value (Table 5 , Row $\mathrm{C}$ ). In general, these values will be specific to the mining firm because the value is specific to 
the type of ore, process operation and a negotiated contract with the firm willing to purchase the residue (lead smelter, mercury recycler).

Separation technology would tend to increase the value of the process residue to buyers because impurities would be removed. In our example, mercury separation technology reduces the concentration of mercury from 1300 to $250 \mathrm{ppm}$ at a cost of $\$ 500 /$ ton (Table 5, Row F). Whether the technology is cost effective depends on how much the value of the process residue increases as the level of mercury in the residue decreases. Researchers and/or separations technologists can estimate the cost of using a new technology.

Mines have existing methods for handling their process residue and could estimate these costs (Table 5, Row G). In our example, the copper mine used a less effective separations technology before using the innovative technology - the cost of this "old technology" would be the "next best" technology referred to in Row $\mathrm{G}$.

Table 5. Economic variables for separation of impurities from process residue

\section{Economic Variable}

\section{Concentration of impurities, ppm}

\begin{tabular}{llccc}
\hline A Value of process residue before separating & $<100$ & $<50$ & $<10$ \\
impurities & need data-may be negative & \\
Value of process residue after separating impurities & & & \\
& & need & need & need \\
B Primary process residue (e.g., acid plant sludge) & data & data & data \\
& & need & need & need \\
C Secondary process residue (e.g., mercury) & data & data & data
\end{tabular}

\section{Gross value after separating impurities}

D Acid plant sludge $(B-A)$

E Secondary process residue $(C-A)$

F Target separation cost per ton for new technology

$G$ Processing cost per ton for existing or next best technology

H Processing cost per ton saved by new technology $(G-F)$

$\begin{array}{ccc}\begin{array}{c}\text { calculate } \\ \text { calculate } \\ \text { depends on } \\ \text { technology } \\ \text { need data }\end{array} & \begin{array}{c}\text { calculate } \\ \text { calculate } \\ \text { tepends on } \\ \text { need data }\end{array} & \begin{array}{c}\text { calculate } \\ \text { calculate } \\ \text { depends on } \\ \text { technology } \\ \text { need data }\end{array} \\ \begin{array}{ccc}\text { calculate } & \text { calculate } & \text { calculate } \\ \text { calculate } & \text { calculate } & \text { calculate } \\ \text { calculate } & \text { calculate } & \text { calculate }\end{array}\end{array}$

Net value of separating impurities

I Primary process residue $(D-F)$

$J$ Secondary process residue $(E-F)$
Impurities removal level for highest net benefit based on highest value for each process residue

Primary process residue

Secondary process residue
Highest value in row I

Highest value in row $\mathrm{J}$

By using the heuristic model, cost savings per ton of material processed using a new technology, and the net value of separating impurities from process residue can be calculated. Costs and values, shown in Table 5, are crucial to determining the value of technology that removes impurities. However, those who have this information have incentives not to reveal it. Without this information, developing the technology will be more difficult as potential investors in RD\&D will not be able to 
accurately assess the market potential of a new technology. Because collecting this information is crucial, incentives to withhold information are briefly examined.

The most important incentives for not revealing information about operating costs and process quantities are related to the perception that withholding the information has competitive and regulatory advantages. Published information about a firm's operations and costs could help its competitors. Other firms in the same industry might be able to use the information to improve their own operations, capital investment plans, and marketing strategies relative to the firm that they have information about.

The other incentive for keeping information private is that regulators could use the information to enforce or expand existing regulations. If information about the hazardous nature of process residue is not already available to regulators, then there may be incentives to not reveal such information. Such information could be used to support EPA's claim that process residue should be regulated as waste.

Because of incentives to maintain the confidentiality of cost information, the heuristic model was developed to allow generalized analysis of new technology without revealing sensitive information. Several methods for using the model outlined in Table 5 are listed below. Use of these methods may not generate detailed information, but may help establish a dialogue between representatives of the mining industry and technologists resulting in information useful in technology evaluations.

Generating information through anonymous responses - Information generated through questionnaires could be reported to a trade organization and averaged or reported anonymously. This would protect individual firms from revealing information that could be attributed to them.

Generating information through range responses-Questionnaires could be developed so that answers were provided as ranges. If these ranges were wide enough the individual firms may feel that their specific information is not compromising their competitive position.

Generating information from bottom line responses that do not reveal details - The heuristic model could be filled out to the extent that researchers were comfortable with assumptions about a specific operation. Then the firms that had specific but proprietary information could privately fill out the information they did not want to reveal. Then they could do the calculations providing the researchers with the bottom line answer. As long as the firm supplied more than one variable for the calculation, proprietary information would be protected. An alternative would be to ask the firms to indicate whether the bottom line was higher or lower than an investment hurdle or to set up the model so that the firm can calculate a breakeven cost for the technology being investigated.

Using the heuristic model as a basis for qualitative evaluation of the technology-The heuristic model could be used as the basis for a qualitative interview/discussion with individual firms or mining representatives. Specific strawman (quantitative) assumptions could be included in the model to provide a basis for discussion. The interview could help establish whether the model was complete and representative of the residuals processing without revealing proprietary quantitative information. This approach could go a long way towards establishing communication between the researchers and the mining firms.

Providing sufficient information to promote voluntary cooperation-Individually or in combination, the above methods may provide the mining industry or individual firms with enough information about the technology that they may wish to cooperate because the technology promises significant benefits. Individual firms or the industry as a whole will probably be increasingly willing to share information if it can be shown that the development of a technology could provide significant benefits.

One or more of the above approaches may provide valuable information that helps the researcher and decision maker gain information for evaluating the potential of a new technology. 


\section{SUMMARY}

This report points out opportunities for the mining industry to improve operations by responsible emission and by-product management and low-cost and efficient production. The dialogue between the mining industry, government, and the research community has strengthened the potential to capture these opportunities and can help realize $A$ Vision of the Mining Industry of the Future (DOE 1998).

ORNL engineers developed simplified descriptions of copper, lead, and zinc processes that can serve as a basis for more specific dialogue on identifying by-product recovery opportunities and further clarifying those by-product recovery opportunities that could benefit from joint research by industry and government. By identifying highly beneficial opportunities for by-product recovery, it is hoped that research will result in development of technologies that contribute to a more profitable, safer, and environmentally benign U.S. mining industry.

This paper identifies process residues by mine type as

- copper-dust and fine particles, tailings, slag waste, and gas cleaning sludge;

- lead-dust and fine particles, tailings, slag; and

- zinc-dust and fine particles, liquor residues, suppression of undesirable elements in solution, slag.

Opportunities for technology development that result in economical recovery of by-products in the mining industry can be clarified by evaluating data on the value of process residue before separating impurities, after separation, and the cost of separation. Methods for Identifying Opportunities for Economical By-products Recovery in the Metals Mining Industry presents methods for using a heuristic model to evaluate variables that influence the economics of separating impurities from process residue (Table 5). Such an economic evaluation would provide information on a technology's market potential and help guide decisions regarding investments in technology development.

\section{REFERENCES}

Biswas, A.K., and Davenport, W.G. 1994. Extractive Metallurgy of Copper, 3rd ed., Pergamon Press, Oxford.

Cox, P.A. 1997. The Elements: Their Origin, Abundance, and Distribution, Chap. 1, rev. 1990, Oxford University Press, New York.

DOE (U.S. Department of Energy) 1980. An Assessment of Energy Requirements in Proven and New Copper Processes, DOE/CS/40132, University of Utah, Salt Lake City.

DOE (U.S. Department of Energy) 1998. The Future Begins With Mining, A Vision of the Mining Industry of the Future, Office of Industrial Technologies, Washington, D.C.

EPA (U.S. Environmental Protection Agency) 1994. Technical Resource Document: Extraction and Beneficiation of Ores and Minerals, EPA 530-R-94-031 (NTIS PB94-200979), vol. 4, Washington, D.C.

EPA (U.S. Environmental Protection Agency) 1998. Technical Background Document: Identification and Description of Mineral Processing Sectors and Waste Streams, RCRA Docket No. F-96PH4A-S0001, EPA Office of Solid Waste, Washington D.C., April.

NMA (National Mining Association) 2001. Personal communication with J.B. Berry, Oak Ridge National Laboratory, Oak Ridge, Tenn., April 2000. 
NRC (National Research Council) 2001. Evolutionary and Revolutionary Technologies for Mining, National Academy Press, March.

Patton, H.W. 2000. Patton Engineering and Consulting, Inc., personal communication with J.B. Berry, Oak Ridge National Laboratory, Oak Ridge, Tenn., April 2000.

Peterson, D.J., LaTourrette, T., and Bartis, J.T. 2001. New Forces at Work in Mining: Industry Views of Critical Technologies, Rand Publications.

Ullmann's 1993. Ullmann's Encyclopedia of Industrial Chemistry, VCH Publishers, Inc., $5^{\text {th }}$ ed.

USGS (U.S. Geological Survey, Mineral Resources Program) 2001. Commodity Statistics and Information, http://minerals.usgs.gov/minerals/pubs/commodity (accessed September 2001).

Wiley, John and Sons, Inc. Encyclopedia of Chemical Technology, 3d ed., 26 vol., 1984. 


\section{Glossary}

Activator-a. In flotation, a chemical added to the pulp (a mixture of ground ore and water) to increase the floatability of a mineral in a froth or to refloat a depressed (sunk) mineral. Also called activating reagent. b. A reagent that affects the surface of minerals in such a way that it is easy for the collector atoms to become attached. It has the opposite effect of a depressor.

Anode slimes-The metals or metal compounds left at, or falling from, the anode (the positive pole in an electrolytic cell) during electrolytic refining of metals.

Autogenous milling-A secondary grinding process of ore or coal using selectively sized media tumbling in a revolving cylinder.

Baghouse-A chamber in which exit gases from roasting, smelting, melting, or calcining are filtered through membranes (bags) that arrest solids such as fine particulates.

Ball mill—A rotating horizontal cylinder with a diameter almost equal to the length supported by a frame or shaft, in which nonmetallic materials are ground using various types of grinding media such as quartz pebbles, porcelain balls, etc.

Beneficiate - To improve the grade by removing associated impurities. Improving the chemical and/or physical properties of ore.

Beneficiation-a. The dressing or processing of ores for the purpose of (1) regulating the size of a desired product, (2) removing unwanted constituents, and (3) improving the quality, purity, or assay grade of a desired product. b. Concentration or other preparation of ore for smelting by drying, flotation, or separation.

Blast furnace-A shaft furnace in which solid fuel is burned with an airblast to smelt ore in a continuous operation.

Blister copper-An impure intermediate product in the refining of copper, produced by blowing copper matte in a converter. (See Matte.)

Calcine-a. Ore or concentrate after treatment by calcination or roasting and ready for smelting. b. To expel, by heating, volatile matter as carbon dioxide, water, or sulfur, with or without oxidation; to roast; to burn (See Calcination, Calcining, Calciner, and Roasting.)

Calcination-a. Heating ores, concentrates, precipitates, or residues to decompose carbonates, hydrates, or other compounds. b. Heating metals at high temperatures to convert them into their oxides.

Calcining-Roasting of ore in oxidizing atmosphere, usually to expel sulfur or carbon dioxide. If sulfur removal is carried to practical completion, the operation is termed "sweet" roasting; if $\mathrm{CO}_{2}$ is virtually removed, "dead" roasting. (See Roasting.)

Calciner-A furnace or kiln in which ores or metallurgical products are calcined. (See Calcine.)

Cementation-The precipitation of a more noble metal from solution by the introduction of a less noble metal.

Chalcophile-Said of an element tending to concentrate in sulfide minerals and ores. Such elements have intermediate electrode potentials and are soluble in iron monosulfide. (Compare Lithophile.) 
Classifier-a. A machine or device for separating the constituents of a mat erial according to relative sizes and densities, thus facilitating concentration and treatment. The term classifier is used in particular where an upward current of water is used to remove fine particles from coarser material. b. In mineral beneficiation, the classifier is a device that takes the ball mill discharge and separates it into two portions - the finished product, which is ground as fine as desired, and oversized material. (See Ball mill and Beneficiation.)

Collector-A compound containing a hydrogen-carbon group and an ionized group, chosen for ability to adsorb selectively in a froth flotation process and render adsorbing surfaces relatively hydrophobic

Cone crusher-A machine for reducing the size of materials by means of a truncated cone revolving on its vertical axis within an outer chamber, the anular space between the outer chamber and cone being tapered. (See also Gyratory crusher.)

Depressor-A substance (usually inorganic) that inhibits flotation of the mineral. (See Activator.)

Electrolyte - A nonmetallic electric conductor (as a solution, liquid, or fused solid) in which current is carried by the movement of ions instead of electrons with the liberation of matter at the electrodes; a liquid ionic conductor.

Electrostatic separation - A method of separating materials by dropping feed material between two electrodes, positive and negative, rotating in opposite directions. Nonrepelled materials drop in a vertical plane; susceptible materials are deposited in a forward position somewhat removed from the vertical plane.

Electrowinning-An electrochemical process in which a metal dissolved within an electrolyte is plated onto an electrode. Used to recover metals such as cobalt, copper, gold, and nickel from solution in the leaching of ores, concentrates, precipitates, etc. (See Electrolyte.)

Eluate - Liquid used to displace captured ions from the zeolite (a generic term for class of hydrated silicates of aluminum and either sodium or calcium or both) or the resin on which they are held; also, in ion exchange processes, solution used for elution. In chromatography, the solution used to displace absorbed substances.

Flotation-A process for separating suspended particles using their relative density in a liquid. Usually, the term is now used to mean froth flotation. (See Froth and Froth flotation.)

Froth - In the flotation process, a collection of bubbles resulting from agitation, the bubbles being the agent for raising (floating) the particles of ore to the surface of the cell. (See Froth flotation.)

Froth flotation-a. A flotation process in which the minerals floated gather in and on the surface of bubbles of air or gas driven into or generated in the liquid in some convenient manner. b. The separating of finely crushed minerals from one another by causing some to float in a froth and others to remain in suspension in the pulp. Oils and various chemicals are used to activate, make floatable, or depress the minerals. c. A process for cleaning fine coal, copper, lead, zinc, phosphate, kaolin, etc. with the aid of a reagent; the coal or minerals become attached to air bubbles in a liquid medium and float as a froth. (See Flotation and Froth.)

Gyratory crusher-A primary crusher consisting of a vertical spindle, the foot of which is mounted in an eccentric bearing within a conical shell. The top carries a conical crushing head revolving eccentrically in a conical maw. There are three types of gyratories--those that have the greatest movement on the smallest lump, those that have equal movement for all lumps, and those that have greatest movement on the largest lump. 
Hydrocyclone-A cyclone separator in which a spray of water is used. (A cyclone separator is a funnel-shaped device for removing material from an airstream by centrifugal force.)

Hydrometallurgy - The treatment of ores, concentrates, and other metal-bearing materials by wet processes, usually involving the solution of some component, and its subsequent recovery from the solution. (Compare Pyrometallurgy.)

Jaw crusher-A primary crusher designed to reduce large rocks or ores to sizes capable of being handled by any of the secondary crushers. It consists of a moving jaw, hinged at one end, which swings toward and away from a stationary jaw in a regular oscillatory cycle.

Leachate-A solution obtained by leaching, which is the extraction of soluble metals or salts from an ore by means of slowly percolating solutions such as water or acids.

Lithophile-a. Said of an element that is concentrated in the silicate rather than in the metal or sulfide phases of meteorites. Such elements concentrate in the Earth's silicate crust in Goldschmidt's tripartite division of elements in the solid Earth. ${ }^{*}$ b. Said of an element with a greater free energy of oxidation per gram of oxygen than iron. It occurs as an oxide and more often as an oxysalt, especially in silicate minerals. (Compare Chalcophile.)

Lixiviant -A liquid medium that selectively extracts the desired metal from the ore or material to be leached rapidly and completely, and from which the desired metal can then be recovered in a concentrated form.

Matte-A metallic sulfide mixture made by melting the roasted product in smelting sulfide ores of copper, lead, and nickel.

Noble-Used in mineralogy to express superiority or purity (e.g., noble metals).

Pyrometallurgy-Metallurgy involved in separating and refining metals in which heat is used, as in roasting and smelting. It is the most important and oldest class of the extractive processes. (See Roasting and Smelting.)

Raffinate-The aqueous solution remaining after a metal has been extracted by a solvent. (See Solvent extraction.)

Reverberatory furnace - A furnace with a shallow hearth and a roof that deflects the flame and radiates heat toward the hearth or the surface of the charge (i.e., the material being fed into the furnace). Firing may be with coal, pulverized coal, oil, or gas. Two of the most important types are the open-hearth steel furnaces and the large reverberatories employed in copper smelting.

Roast-To heat to a point somewhat short of fusing, with access of air, to expel volatile matter or effect oxidation. (Also see Roasting.)

Roasting-a. Heating an ore to effect a chemical change that will facilitate smelting. (See Smelting.) b. The operation of heating sulfide ores in air to convert to oxide or sulfate. c. Calcination, usually with oxidation. "Good," "dead," or "sweet" roasting is complete roasting; that is, it is carried on until sulfurous and arsenious fumes cease to be given off. Kernel roasting is a process of treating poor sulfide copper ores, by roasting in lumps, whereby copper and nickel are concentrated in the interior of the lumps. (See Calcination.) d.The heating of solids, frequently to promote a reaction with a gaseous constituent in the furnace atmosphere.

\footnotetext{
"V.M. Goldschmidt (1888-1947) collected and analyzed vast amount of data regarding the distribution of elements in the earth's crust.
} 
Rod mill-A mill for fine grinding, somewhat similar to a ball mill but employing long steel rods instead of balls to effect the grinding. (See Ball mill.)

Semi-autogenous milling-A grinding in which ore is ground using a combination of steel grinding media and the ore itself.

Sintering-a. A heat treatment for agglomerating small particles to form larger particles, cakes, or masses; in the case of ores and concentrates, it is accomplished by fusion of certain constituents. b. To heat a mass of fine particles for a prolonged time below the melting point, usually to cause agglomeration.

Slag-A substance formed in any one of several ways by chemical action and fusion at furnace operating temperatures: (1) in smelting operations, through the combination of a flux, such as limestone, with the gangue or waste portion of the ore; (2) in the refining of metals, by substances such as lime added for the purpose of effecting or aiding the refining; or (3) by chemical reaction.

Sludge - A semifluid, slushy, murky mass of sediment resulting from treatment of water, sewage, or industrial and mining wastes, such as those from a coal-washing facility.

Smelter-A furnace in which raw materials or ores are melted.

Solvent extraction-A method of separating one or more substances from a mixture by treating a solution of the mixture with a solvent that will dissolve the required substances, leaving the others.

Speiss - The metallic arsenides and antimonides smelted from cobalt and lead ores.

Tailings-a. Any refuse material resulting from the washing, concentration, or treatment of ores. b. Those portions of ore or minerals that are regarded as too poor to be treated further. c. The reject from froth flotation cells. (See Froth flotation.)

Venturi scrubber-Venturi scrubbers are used to collect extremely fine particulate matter from industrial emission sources. They are commonly used to remove particulate matter from exhaust gas streams which are corrosive, flammable, or which contain difficult-to-handle solids. The particulate collection efficiency of a venturi scrubber is comparable to that of an electrostatic precipitator or a fabric filter baghouse. The scrubbers mix particles and liquid, and then use a high-velocity air or gas stream to cause the liquid to become a mist that separates from the heavier solid particles.

Waelz kiln-A kiln in which low-grade ores, slags, or residues (e.g., from a distillation process) may be treated either for the recovery of zinc alone or for the recovery of zinc, lead, and tin. It employs a rotary kiln, and the zinc-bearing material mixed with fine coal is fed into the kiln and heated so that the zinc is vaporized and converted to oxide fume. 


\section{Internal Distribution}

1-5. M. R. Ally

6. J. M. Begovich

7-11. J. B. Berry

12-16. L. R. Dole

17. P. D. Fairchild

18-22. J. J. Ferrada

23. E. C. Fox
24. J. N. Herndon

25-29. J. W. Van Dyke

30. D. L. Williams, Jr.

31. Central Research Library

32. Laboratory Records-RC

33. Laboratory Records-OSTI

\section{External Distribution}

34. Lisa Corathers, National Mining Association, 1130 17th St., NW, Washington, DC 20036.

35. John P. Hager, Ph.D., Hazen Professor and Director, Kroll Institute for Extractive Metallurgy, Dept. of Metallurgical and Materials Engineering, Colorado School of Mines, Golden, CO 80401 